\title{
THE IMPACT OF UNMOWN REFUGE-STRIPS ON THE BREEDING SITE FIDELITY OF COMMON QUAIL (Coturnix coturnix) - A CASE STUDY
}

\author{
Tamás M. Németh \& Dániel Winkler \\ Soproni Egyetem, Vadgazdálkodási és Gerinces Állattani Intézet \\ University of Sopron, Institute of Wildlife Management and Vertebrate Zoology \\ H-9400 Sopron, Bajcsy-Zs u. 4., Hungary \\ e-mail: tomanemeth@gmail.com; winkler.daniel@uni-sopron.hu
}

\begin{abstract}
NÉMETH, T.M. \& WINKLER, D.: THE IMPACT OF UNMOWN REFUGE-STRIPS ON THE BREEDING SITE FIDELITY OF COMMON QUAIL (Coturnix coturnix) - A CASE STUDY. Hungarian Small Game Bulletin 13: 289-296. http://dx.doi.org/10.17243/mavk.2017.289

Common Quail (Coturnix coturnix) mainly breed in cereal crops and fallow grasslands, where they are threatened by harvesting/mowing. The aim of this research was to assess the impact of unmown refuge areas to the density and movements of Common Quails in the Moson Project, Northwest Hungary. The selected 80 ha study area was first visited shortly before mowing, while the second survey was carried out two weeks after mowing operation ended. Calling males of Common Quail were documented and their vocalizations were recoded. During the first survey (before mowing), a total of 18 Common Quails were recorded, while the second survey (after mowing) resulted in a lower number (14) of birds detected. In terms of density, the initially determined 2.25 calling males/10 ha decreased to 1.75 males/10 ha. For individual recognition bioacoustic methods were used. A total of six time and frequency-based variables were measured and were subjected to discriminant function analysis (DFA). A total of 9 males were re-identified with high probability, proving that the $15-20 \mathrm{~m}$ wide unmown refuge-srips can still provide optimal habitats for quails.
\end{abstract}

KEY WORDS: farmland birds, mowing, refuge areas, agricultural practices, habitat selection

\section{KIVONAT}

NÉMETH T.M. \& WINKLER D.: BÚVÓSÁVOK HATÁSA A FÜRJ (Coturnix coturnix) TERÜLETHÜSÉGÉRE FÉSZKELÉSI IDŐSZAKBAN - ESETTANULMÁNY. Magyar Apróvad Közlemények 13: 289-296. http://dx.doi.org/10.17243/mavk.2017.289

A fürj (Coturnix coturnix) a mezei élöhelyek jellegzetes fészkelő madara. Költ a különböző mezőgazdasági kultúrákban, ugar jellegü élőhelyeken, ahol a betakarítás illetve kaszálás nagy veszélyt jelent a fészkelési időszakban. Jelen kutatás a kaszálatlanul hagyott búvósávok szerepét vizsgálja a fürjek denzitása valamint területhüsége vonatkozásában egy északnyugat-magyarországi élőhelyen (MOSON Project). A fürjek felmérésére a vizsgálatokhoz kiválasztott mintegy 80 hektár nagyságú területen először a kaszálás időpontja elött, majd ezt követően a kaszálás befejezése után két héttel került sor. Az éneklő kakasok számának feljegyzése mellett hangfelvételeket is készítettünk. Az első felmérés során összesen 18, majd a kaszálás után 14 hím egyedet detektáltunk, így a denzitás 2.25 éneklő kakas/10 ha-ról 1.75 éneklő kakas/10 ha értékre csökkent a kaszálást követően. Az éneklő hím egyedek elkülönítése bioakusztikai módszerekkel történt, amihez a fürj hangját jól reprezentáló hat hangfizikai változó mérését végeztük el a rögzített hangmintákon. A hangfizikai változók adatmátrixát diszkriminancia-analízis (DFA) segítségével elemeztük. Összesen 9 fürj kakas újraazonosítása sikerült nagy biztonsággal, amely alapján azt a következtetést vonhatjuk le, hogy a kaszálatlanul hagyott 15-20 m széles búvósávok megfelelő élőhelyet tudnak biztosítani a fürj számára.

KEY WORDS: mezei madárfajok, kaszálás, búvósávok, mezőgazdasági üzemmód, élőhelyválasztás 


\section{INTRODUCTION}

The Common Quail (Coturnix coturnix) is a widely distributed breeding species mostly associated with farmland areas in Europe (CRAMP, 1980; MCGOWAN et al. 2013). The population trend declining in many European countries (BIRDLIFE INTERNATIONAL, 2016) owing to the intensive agricultural practices, the use of pesticides and heightened mortality during migration (SANDERSON et al., 2009, KOSICKI et al., 2014). Additionally, Common Quails are subjected to significant hunting pressure during the autumn migration period, especially in the Mediterranean countries (TUCKER \& HEATH, 1994; GALLEGO et al., 1997; PUIGCERVER et al., 1998). In Hungary, the Common Quail is a protected species. Nevertheless, its population shows moderate decline both locally and countrywide (NÉMETH et al., 2014; MAGYAR MADÁRTANI ÉS TERMÉSZETVÉDELMI EGYESÜLET, 2017).

In Hungary, major threats are mainly linked to agricultural practices (MÁRKUS, 1998; BÁLDI \& BATÁRY, 2011; NÉMETH et al., 2014; FARAGÓ, 2015). Since harvesting and mowing often takes place during the breeding season, both chicks and nesting birds are often killed by these processes (BROYER 1996, RODRÍGUEZ-TEIJEIRO et al., 2009). Some studies revealed, the harvesting and mowing processes may be pushing Common Quails to search new breeding habitats (PUIGCERVER et al., 1999; RODRÍGUEZ-TEIJEIRO et al., 2009). Unmown refuge-strips can, however, have a positive effect on the survival of farmland birds, and can henceforth provide breeding habitat for the birds in the same site (BROYER 2003).

The main goal of this study was to assess the impact of the unmown refuge-strips on the density and breeding site fidelity of the Common Quail in an extensively managed area (MOSON Project) in Western Hungary.

\section{MATERIAL AND METHODS}

\subsection{STUDY AREA}

The research was carried out in the area of the MOSON Project (Fig. 1), situated in the Little Hungarian Plain (Northwest Hungary) underlain by alluvial deposits (mainly gravel from the River Danube) and silty loess, which result in thin, poor soils (DÖVÉNYI, 2010). The MOSON Project was launched on a former agricultural production site and covers 880 hectares. The main goal of the project was to increase the population of Great Bustard (Otis tarda) and Grey Partridge (Perdix perdix) and simultaneously of other farmland birs like the Common Quail, the Pheasant (Phasianus colchicus) or the passerine Corn Bunting (Emberiza calandra) by cultivating the field with ecologically sustainable methods (FARAGO \& GICZI, 1997; FARAGÓ \& KALMÁR, 2006). In the area traditional plant production systems with regular fallowing are dominant. About $80 \%$ of the project area is left fallow each year. The use of pesticides is restricted and there is no cultivation after April until harvesting (OECD 2008).

For the survey an approximately 80 ha area was selected, maintained by partial mowing leaving 15-20 $\mathrm{m}$ wide unmown strips in the field.

\subsection{SuRVEY OF COMMON QUAILS}

Vocal individuality has been proved to be a useful tool for accurate bird censi (MCGregor \& PEAKe, 1998; GILBERT et al., 1994; WinKLER at al., 2014; XiA et al., 2017). Individual differences in Common Quail calls were demonstrated by COLLINS \& GOLDSMITH 
(1998), their method of analysis was roughly followed in our study. Common Quail surveys were conducted twice during the breeding season of 2015. The first survey was carried out at the end of June, one week prior to the beginning of mowing, while the second survey was undertaken mid June, nearly two weeks after mowing operation ended. By walking on the NW-SE cartroad bisecting the survey area (Fig. 1), Common Quail vocalizations were recorded using a linear PCM recorder (Olympus LS-5) and shotgun microphone (type RØDE NTG4+). The accuracy of the calling males' position was estimated to be within $50 \mathrm{~m}$ and was also mapped.

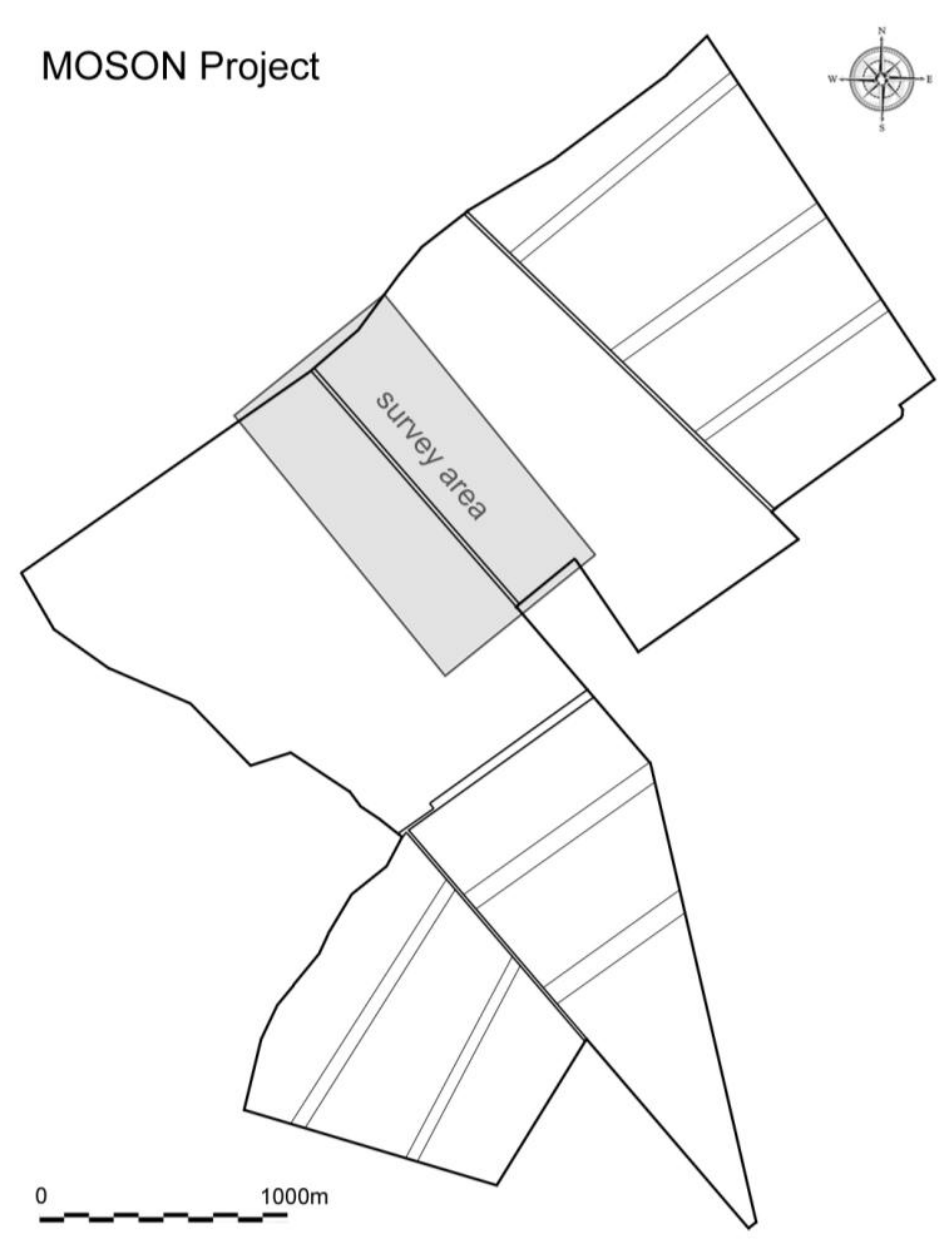

Figure 1: Study area within the MOSON Project

\subsection{ANALYSIS OF RECORDINGS}

Common Quail vocalizations were recorded in lossless .wav format with a sampling rate of 16bit $-44.1 \mathrm{kHz}$. Sonograms of the recorded calls were analysed using the software Adobe Audition 3.0. Collins \& GolDSMITH (1998) used a total of seven frequency and time variables to characterize Common Quail vocalization: apart from the fundamental frequency and duration of each syllable, the time gaps between syllable 1 and syllable 2 were determined. In our analyses, the following six variables were used: intersyllable intervals (isil, isi2 and isi3, respectively) and peak frequency (frequency with the most energy) of each syllables $\left(f_{\text {peak }} 1, f_{\text {peak }} 2\right.$ and $f_{\text {peak }} 3$, respectively) (Fig. 2). These parameters are easily measurable with high accuracy, while the duration of syllable 1 and 3 , as well as the gap 
between the first two syllables used by ColLins \& GOLDSMITH (1998) can hardly be determined in case when background noises (e.g. wind noise, song of passerines, orthopterans) are present. Durations were measured using the Time Selection Tool, while peak frequencies were determined with the help of the Frequency Analysis Tool within the Adobe Audition software.

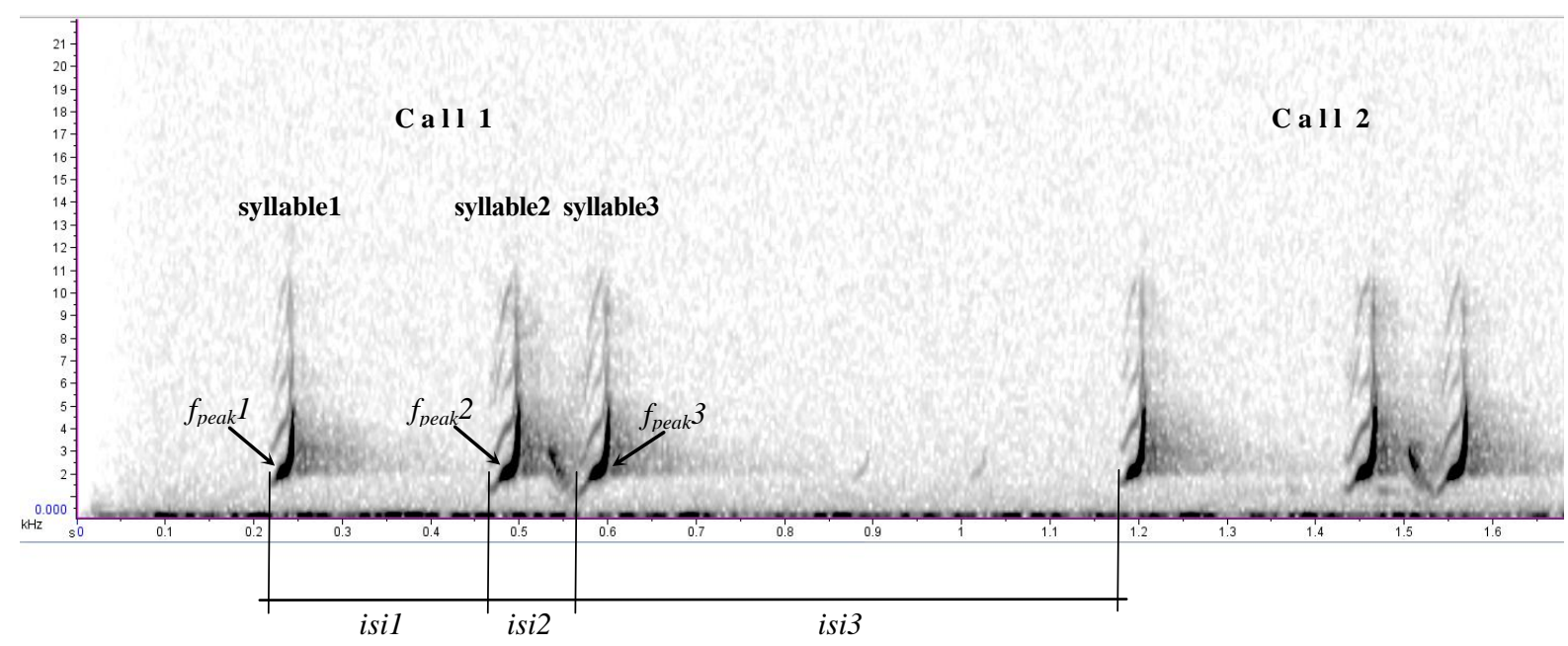

Figure 2: Sonogram of a Common Quail call recorded in the MOSON Project

(isi 1 - interval between syllable 1 and 2; isi2 - interval between syllable 2 and 3; isi3 - interval between syllable 3 and syllable 1 of the consecutive call; $f_{\text {peak }} l-3$ - peak frequency of syllable 1-3)

\subsection{QUANTITATIVE ANALYSIS}

The measured parameters were used to perform a stepwise cross-validated discriminant function analysis (DFA). A total of 20 consecutive Common Quail calls were measured of each character for every individuals, so as to meet the requirement for the recommended adequate number (at least three times as large as the number of the measured parameters) of calls (WILLIAMS \& TITUS, 1988). For re-identification of individual birds, Euclidean distance measure was used. Individual variables of re-identified calls were tested with paired samples $t$ test. Statistical analyses were performed using SPSS Version 22 (IBM Corp., Armonk, New York).

\section{RESULTS}

During the first survey (before mowing - BM), a total of 18 Common Quails were recorded, while the second survey (after mowing - AM) resulted in a lower number (14) of birds detected. In terms of density, the initially determined 2.25 calling males/10 ha decreased to 1.75 males/10 ha.

Parameter datasets of recorded Common Quail calls are presented in Tab. 2. To exclude the possibility of double counts within the same survey, and to re-identify individual birds recorded in the second survey, discriminant function analysis (DFA) was applied. The analyses classified more than $94 \%$ of the Common Quail calls to the correct individuals in both surveys. The stepwise discrimination selected all six variables originally entered in the 
analyses. The first three discriminant functions explained more than $95 \%$ of the total variance. Variables that contributed the most to the discrimination were the peak frequency of the second syllable $\left(F_{\text {peak }} 2\right)$, the intersyllable interval between the first and second syllables (isil) and the intersyllable interval between the second and the third syllables (isi2).

Table 1: Values (Mean \pm SD) of the recorded Common Quail call parameters

(For abbreviations see legend of Fig. 2)

\begin{tabular}{|c|c|c|c|c|c|c|}
\hline \multirow{2}{*}{$\begin{array}{c}\text { Code of } \\
\text { quails }\end{array}$} & isil $(\mathrm{sec})$ & $i s i 2(\mathrm{sec})$ & isi3 $(\mathrm{sec})$ & $f_{\text {peak }} l(\mathrm{~Hz})$ & $f_{\text {peak }} 2(\mathrm{~Hz})$ & $f_{\text {peak }} 3(\mathrm{~Hz})$ \\
\hline & \multicolumn{6}{|c|}{ quails recorded before mowing (BM) } \\
\hline BM1 & $0.215 \pm 0.002$ & $0.127 \pm 0.002$ & $0.630 \pm 0.013$ & $2090.1 \pm 2.997$ & $2131.2 \pm 1.581$ & $2040.8 \pm 1.885$ \\
\hline BM2 & $0.256 \pm 0.004$ & $0.103 \pm 0.002$ & $0.606 \pm 0.016$ & $2088.7 \pm 4.400$ & $2040.6 \pm 5.423$ & $2045.1 \pm 2.232$ \\
\hline BM3 & $0.213 \pm 0.003$ & $0.111 \pm 0.001$ & $0.667 \pm 0.018$ & $1962.9 \pm 2.825$ & $1967.8 \pm 12.620$ & $1967.2 \pm 11.805$ \\
\hline BM4 & $0.322 \pm 0.006$ & $0.113 \pm 0.002$ & $0.598 \pm 0.019$ & $2132.8 \pm 1.553$ & $2130.8 \pm 2.167$ & $2170.0 \pm 2.619$ \\
\hline BM5 & $0.244 \pm 0.004$ & $0.126 \pm 0.001$ & $0.649 \pm 0.020$ & $2006.7 \pm 1.488$ & $2005.7 \pm 2.493$ & $2002.8 \pm 3.603$ \\
\hline BM6 & $0.191 \pm 0.004$ & $0.104 \pm 0.001$ & $0.679 \pm 0.021$ & $2130.6 \pm 4.596$ & $2129.6 \pm 1.768$ & $2088.0 \pm 4.036$ \\
\hline BM7 & $0.160 \pm 0.003$ & $0.085 \pm 0.001$ & $0.572 \pm 0.013$ & $2110.3 \pm 5.731$ & $2130.3 \pm 3.777$ & $2132.0 \pm 4.209$ \\
\hline BM8 & $0.201 \pm 0.002$ & $0.118 \pm 0.001$ & $0.577 \pm 0.030$ & $2006.0 \pm 2.268$ & $2000.1 \pm 9.125$ & $2004.3 \pm 4.534$ \\
\hline BM9 & $0.266 \pm 0.003$ & $0.118 \pm 0.002$ & $0.700 \pm 0.061$ & 2002.8 & 2003 & $2002.7 \pm 4.268$ \\
\hline BM10 & $83 \pm 0.002$ & $0.137 \pm 0.002$ & $0.615 \pm 0.025$ & $2049.6 \pm 4.438$ & $2049.2 \pm 3.284$ & $2051.0 \pm 6.000$ \\
\hline BM11 & $0.187 \pm 0.004$ & $0.102 \pm 0.001$ & $0.607 \pm 0.016$ & $1996.5 \pm 2.878$ & $1994.6 \pm 2.138$ & $1994.0 \pm 4.309$ \\
\hline BM12 & $0.235 \pm 0.005$ & $0.150 \pm 0.003$ & $0.593 \pm 0.025$ & 1992. & -3.370 & $1991.6 \pm 4.406$ \\
\hline BM13 & $0.234 \pm 0.002$ & $0.129 \pm 0.001$ & $0.621 \pm 0.020$ & $2043.7 \pm 3.105$ & 2042. & $2042.0 \pm 1.690$ \\
\hline BM14 & $0.267 \pm 0.004$ & $0.127 \pm 0.002$ & $0.566 \pm 0.015$ & $1997.0 \pm 2.138$ & $1997.4 \pm 1.669$ & $1996.3 \pm 1.923$ \\
\hline BM15 & $0.213 \pm 0.003$ & $0.099 \pm 0.002$ & $0.723 \pm 0.043$ & $2048.3 \pm 3.503$ & $2047.7 \pm 3.327$ & $1961.7 \pm 3.926$ \\
\hline BM16 & $0.183 \pm 0.003$ & $0.093 \pm 0.002$ & $0.776 \pm 0.055$ & $2049.4 \pm 4.811$ & 55.027 & $2086.0 \pm 14.590$ \\
\hline BM17 & $0.258 \pm 0.004$ & $0.130 \pm 0.002$ & $0.683 \pm 0.019$ & $1896.2 \pm 3.655$ & $1897.1 \pm 4.581$ & $1901.6 \pm 3.420$ \\
\hline \multirow[t]{2}{*}{ BM18 } & $0.238 \pm 0.004$ & $0.118 \pm 0.002$ & $0.707 \pm 0.031$ & $2261.6 \pm 3.249$ & $2259.6 \pm 1.847$ & $2261.7 \pm 1.753$ \\
\hline & \multicolumn{6}{|c|}{ quails recorded after mowing (AM) } \\
\hline AM1 & $57 \pm 0.003$ & $02 \pm 0.002$ & $0.603 \pm 0.015$ & $2087.1 \pm 2.800$ & $2041.3 \pm 3.105$ & $2044.6 \pm 2.722$ \\
\hline AM2 & $0.212 \pm 0.002$ & $0.110 \pm 0.001$ & $0.679 \pm 0.019$ & $1961.5 \pm 2.777$ & $1963.7 \pm 4.991$ & $1965.1 \pm 3.727$ \\
\hline AM3 & $0.237 \pm 0.003$ & $0.121 \pm 0.003$ & $0.629 \pm 0.018$ & $1839.8 \pm 1.885$ & $1838.8 \pm 1.885$ & $1848.2 \pm 2.816$ \\
\hline AM4 & $0.220 \pm 0.003$ & $0.108 \pm 0.002$ & $0.805 \pm 0.052$ & $2088.5 \pm 1.927$ & $2087.0 \pm 1.927$ & $2000.1 \pm 7.553$ \\
\hline AM5 & $0.192 \pm 0.003$ & $0.104 \pm 0.001$ & $0.683 \pm 0.023$ & $2131.8 \pm 2.748$ & $2129.8 \pm 1.727$ & $2086.7 \pm 4.367$ \\
\hline AM6 & $0.320 \pm 0.003$ & $0.112 \pm 0.002$ & $0.601 \pm 0.017$ & $2133.2 \pm 1.165$ & $2132.2 \pm 1.553$ & $2171.0 \pm 2.828$ \\
\hline AM7 & $0.271 \pm 0.002$ & $0.116 \pm 0.004$ & $0.583 \pm 0.034$ & $2041.5 \pm 2.204$ & $2042.2 \pm 1.685$ & $2041.7 \pm 1.282$ \\
\hline AM8 & $0.257 \pm 0.002$ & $0.130 \pm 0.002$ & $0.689 \pm 0.021$ & $1897.4 \pm 2.507$ & $1898.6 \pm 3.335$ & $1902.8 \pm 2.031$ \\
\hline AM9 & $0.186 \pm 0.003$ & $0.102 \pm 0.001$ & $0.616 \pm 0.022$ & $1995.2 \pm 2.188$ & $1995.5 \pm 2.138$ & $1994.2 \pm 2.915$ \\
\hline AM10 & $0.235 \pm 0.004$ & $0.151 \pm 0.001$ & $0.600 \pm 0.021$ & $1993.9 \pm 3.137$ & $1995.1 \pm 2.532$ & $1988.5 \pm 3.857$ \\
\hline AM11 & $0.265 \pm 0.003$ & $0.127 \pm 0.001$ & $0.573 \pm 0.023$ & $1996.1 \pm 1.959$ & $1997.3 \pm 1.302$ & $1995.2 \pm 1.832$ \\
\hline AM12 & $0.159 \pm 0.003$ & $0.085 \pm 0.001$ & $0.566 \pm 0.016$ & $2112.2 \pm 3.834$ & $2132.1 \pm 2.696$ & $2131.6 \pm 2.504$ \\
\hline AM13 & $0.253 \pm 0.004$ & $0.102 \pm 0.002$ & $0.656 \pm 0.020$ & $2196.5 \pm 12.843$ & $2068.8 \pm 21.570$ & $2105.7 \pm 31.486$ \\
\hline AM14 & $0.203 \pm 0.005$ & $0.114 \pm 0.002$ & $0.840 \pm 0.069$ & $2032.7 \pm 1.581$ & $2034.1 \pm 3.991$ & $2036.8 \pm 2.835$ \\
\hline
\end{tabular}

Discrimination of the Common Quail calls recorded in the different surveys (before and after mowing) showed high degree of similarity in 9 cases based on the Euclidean distances between group centroids in the multidimensional space. According to these results, recognition of individuals was possible in the following cases (for codes see Tab. 1): BM2AM1; BM3-AM2; BM4-AM6; BM6-AM5; BM7-AM12; BM11-AM9; BM12-AM10; BM14-AM11; BM17-AM8. Subsequently, we compared all measured parameters (paired 
samples $t$ test) to confirm the individual recognition (Tab. 2). Comparisons resulted in no significant differences with the exception of two cases. Peak frequency of syllable 2 differed significantly between calls/birds coded BM4 and AM6, while interval between syllable 1 and 2 varied significantly while comparing calls BM11 and AM9. In both cases only a single variable was affected. As randomly selected set of calls showed similar within-individual variation for these two variables, we can conclude that the 9 quails were re-identified with high probability. The individuals recorded after moving (AM) mostly aggregated in the refuge-strips, only two birds were calling in the mowed open area.

Table 2: Comparison of call variables (paired sample $t$ test) of the individuals re-identified with discrimination (For abbreviations see legend of Fig. 2)

\begin{tabular}{|l|c|c|c|c|c|c|}
\hline \multicolumn{1}{|c|}{ Code of quails } & isi1 & isi2 & isi3 & $f_{\text {peak }} 1$ & $f_{\text {peak }} 2$ & $f_{\text {peak }} 3$ \\
\hline \multirow{2}{*}{ BM2 - AM1 } & $t=-0.382$ & $t=-0.491$ & $t=0.910$ & $t=1.328$ & $t=-0.741$ & $t=0.404$ \\
& $p=0.714$ & $p=0.638$ & $p=0.393$ & $p=0.226$ & $p=0.638$ & $p=0.699$ \\
\hline \multirow{2}{*}{ BM3 - AM2 } & $t=0.798$ & $t=1.323$ & $t=-1.737$ & $t=1.760$ & $t=0.932$ & $t=0.569$ \\
& $p=0.451$ & $p=0.228$ & $p=0.126$ & $p=0.123$ & $p=0.383$ & $p=0.587$ \\
\hline \multirow{2}{*}{ BM4 - AM6 } & $t=1.416$ & $t=1.798$ & $t=-0.957$ & $t=-2.049$ & $t=-2.246$ & $t=-1.871$ \\
& $p=0.199$ & $p=0.451$ & $p=0.370$ & $p=0.079$ & $p=\mathbf{0 . 0 4 9}$ & $p=0.104$ \\
\hline \multirow{2}{*}{ BM6 - AM5 } & $t=-1.825$ & $t=2.049$ & $t=-0.571$ & $t=-1.193$ & $t=-1.528$ & $t=0.967$ \\
& $p=0.111$ & $p=0.080$ & $p=0.586$ & $p=0.272$ & $p=0.171$ & $p=0.366$ \\
\hline \multirow{2}{*}{ BM7 - AM12 } & $t=1.174$ & $t=0.798$ & $t=1.134$ & $t=-1.618$ & $t=-1.571$ & $t=0.414$ \\
& $p=0.279$ & $p=0.451$ & $p=0.294$ & $p=0.149$ & $p=0.160$ & $p=0.691$ \\
\hline \multirow{2}{*}{ BM11-AM9 } & $t=2.826$ & $t=1.821$ & $t=-1.331$ & $t=1.452$ & $t=1.871$ & $t=-1.091$ \\
& $p=\mathbf{0 . 0 2 6}$ & $p=0.112$ & $p=0.225$ & $p=0.189$ & $p=0.104$ & $p=0.311$ \\
\hline \multirow{2}{*}{ BM12-AM10 } & $t=0.832$ & $t=-0.856$ & $t=-1.527$ & $t=-1.515$ & $t=-0.532$ & $t=1.917$ \\
& $p=0.439$ & $p=0.421$ & $p=0.171$ & $p=0.174$ & $p=0.612$ & $p=0.097$ \\
\hline \multirow{2}{*}{ BM14- AM11 } & $t=1.644$ & $t=-1.488$ & $t=-1.117$ & $t=1.507$ & $t=1.426$ & $t=1.688$ \\
& $p=0.144$ & $p=0.180$ & $p=0.300$ & $p=0.176$ & $p=0.197$ & $p=0.135$ \\
\hline \multirow{2}{*}{ BM17-AM8 } & $t=1.476$ & $t=1.871$ & $t=-1.441$ & $t=-1.488$ & $t=-1.426$ & $t=-1.452$ \\
& $p=0.183$ & $p=0.104$ & $p=0.193$ & $p=0.180$ & $p=0.197$ & $p=0.189$ \\
\hline
\end{tabular}

\section{DISCUSSION}

As result of our surveys revealed, leaving uncut refuge-strips in grassland area can have positive impact both on the survival and the site fidelity of Common Quails. As the second survey results indicated, there was only a slight decrease in calling males density. Based on the recorded calls, several birds have been re-identified proving that the uncut strips can still provide suitable foraging and nesting habitat for Common Quails, despite the fact that this species is reported to be highly nomadic during the breading season in some regions (HERRMANN \& DASSOW, 2006). As foreign researches showed, in the course of harvesting and mowing Common Quails are consequently moving to new optimal habitats for breeding (PuigCerver et al., 1999; RodrígueZ-TEIJEIRo et al., 2009). The five birds detected only during the second survey after mowing might have arrived from completely harvested or mown neighbouring areas.

Several studies emphasized the positive effects of unmown refuge areas on the survival of farmland birds (VICKERY et al. 2001; BROYER 2003; ARBEITER et al. 2017). In the MOSON Project, apart from the Common Quails, bird species that benefit from the uncut grass strips include the vulnerable Great Bustard (Otis tarda), the Grey Partridge (Perdix 
perdix), the Pheasant (Phasianus colchicus) as well as passerines like the Skylark (Alauda arvensis), the Yellow Wagtail (Motacilla flava), the Whinchat (Saxicola rubetra) and the Corn Bunting (Emberiza calandra). On the other hand, unmown refuge-strips are attractive enough also for predator species (LÓRÁNT et al., 2008). Apart from birds of prey, species of corvid like the Magpie (Pica pica) and the Hooded Crow (Corvus cornix), as well as mammal predators such as the Red Fox (Vulpes vulpes) are efficient predators in the area and can therefore affect the beneficial effects of the unmown refuge-strips.

\section{Acknowledgements}

The study was supported by the project “Agrárklíma.2 VKSZ-12-1-2013-0034”.

\section{REFERENCES}

Arbeiter, S., Helmecke, A. \& Bellebaum, J. (2017): Do Corncrakes Crex crex benefit from unmown refuge strips? Bird Conservation International: 1-8. https://doi.org/10.1017/S0959270916000447

BÁLDI, A. \& BATÁRY, P. (2011): The past and future of farmland birds in Hungary. Bird Study 58(3): 365-377. http://dx.doi.org/10.1080/00063657.2011.588685

BIRDLIFE INTERNATIONAL (2016): Coturnix coturnix. The IUCN Red List of Threatened Species 2016: e.T22678944A85846515. http://dx.doi.org/10.2305/IUCN.UK.2016-3.RLTS.T22678944A85846515.en.

BROYER, J. (1996): Les fenaisons centrifuges, une méthode pour réduire la mortalité des jeunes Râles de genêts Crex crex et Cailles des blés Coturnix coturnix. Revue d'Écologie 51(3): 269-276.

BROYER, J. (2003): Unmown refuge areas and their influence on the survival of grassland birds in the Saône valley (France). Biodiversity and Conservation 12: 1219-1237.

Collins, S. A. \& Goldsmith, A. R. (1998): Individual and Species Differences in Quail Calls (Coturnix c. japonica, C. c. coturnix and a Hybrid). Ethology 104: 977-990. https://doi.org/10.1111/j.1439-0310.1998.tb00047.x

DöVÉNYI Z. (szerk.) (2010): Magyarország kistájainak katasztere. MTA Földrajztudományi Kutatóintézet, Budapest.

FARAGÓ S. \& GICZI F. (1997): Új lehetőségek a túzok (Otis tarda) védelmében. Egy esettanulmány: A MOSON Project. [New possibilities in Great Bustard (Otis tarda) conservation. A case study: The MOSON Project]. Magyar Apróvad Közlemények 12: 125-134.

FARAGÓ S. \& KALMÁR S. (2006): A túzok védelme Magyarországon, Life Nature Project 2005. évi monitoring jelentése. Magyar Apróvad Közlemények, 2006. évi különszám: 12-15.

FARAGÓ S. (2015): Vadászati állattan. Mezőgazda kiadó, Budapest.

GiLBERT, G., MCGREGOR, P.K. \& TYLER, G. (1994): Vocal individuality as a census tool: practical considerations illustrated by a study of two rare species. Journal of Field Ornithology 65: 335348.

Herrmann, M. \& Dassow, A. (2006): Quail Coturnix coturnix. In: Flade, M., Plachter, H., SCHMIDT, R. \& WERNER, A. (eds.): Nature conservation in agricultural ecosystems: results of the Schorfheide-Chorin Research Project. Quelle \& Meyer Verlag, Wiebelsheim, pp. 194-203.

LÓRÁNT M., NÉMETH Á. \& VADÁSz Cs. (2008): A lucerna kaszálások hatása a talajon fészkelő madárfajok költési sikerére a Kiskunságban. In: Abstracts of the V. Hungarian Conservation Biology Congress. Hungarian Biological Society, Budapest, p. 92.

MAGYAR MADÁRTANI ÉS TERMÉSZETVÉDELMI EGYESÜLET (2017): Magyarország madarai: Fürj. http://www.mme.hu/magyarorszagmadarai/madaradatbazis-cotcot Letöltés dátuma: 2017-11-02 
MÁRKUS F. (1998): Fürj (Coturnix coturnix). In: HARASZTHY L. (szerk.): Magyarország madarai. Mezőgazda Kiadó, Budapest. pp. 109-110.

McGowan, P.J.K., DE JUANA, E. \& BoESMAN, P. (2013): Common Quail (Coturnix coturnix). In: DEl Hoyo, J., ElliotT, A., SARgatal, J., Christie, D.A. \& DE JuAnA, E. (eds): Handbook of the Birds of the World Alive, Lynx Edicions, Barcelona.

MCGREGOR, P.K. \& PEAKE, T.M. (1998): The role of individual identification in conservation Biology. In: CARO, T. (ed.): Behavioural ecology and conservation biology. Oxford: Oxford University Press; pp. 31-55.

NÉMETH T.M., WinKLeR D. \& FARAGÓ S. (2014): A Lajta Project fürj (Coturnix coturnix LinNAeus, 1758) állományának vizsgálata a 2013-2014 időszakban. Magyar Apróvad Közlemények 12: 125-134. http://dx.doi.org/10.17243/mavk.2014.125

OECD (2008): OECD Environmental Performance Reviews Hungary. Organisation for Economic Cooperation and Development, Paris.

PUIGCERVER, M., RodRIGUEZ-TEIJEIRO, J.D. \& GALlEGO, S. (1999): The effects of rainfall on wild populations of Common Quail (Coturnix coturnix). Journal für Ornithologie 140(3): 335-340. http://dx.doi.org/10.1007/BF01651030

Rodríguez-Teijeiro, J.D., SArdÀ-Palomera, F., Nadal, J., Ferrer, X., Ponz C. \& Puigcerver, M. (2009): The effects of mowing and agricultural landscape management on population movements of the common quail. Journal of Biogeography 36(10): 1891-1898. http://dx.doi.org/10.1111/j.1365-2699.2009.02109.x

SAnderson, F.J., Kloch, A., SAChanowicz, K. \& Donald, P.F. (2009): Predicting the effect of agricultural change on farmland bird populations in Poland. Agriculture, Ecosystems \& Environment 129: 37-42. https://doi.org/10.1016/j.agee.2008.07.001

TUCKER, G.M. \& HEATH, M.F. (1994): Birds in Europe: their conservation status. BirdLife International, Cambridge, U.K.

Vickery, J.A., Tallowin, J.R., Feber, R.E., Asteraki, E.J., AtKinson, P.W., Fuller, R.J. \& BROWN, V.K. (2001): The management of lowland neutral grasslands in Britain: effects of agricultural practices on birds and their food resources. Journal of Applied Ecology 38: 647664. https://doi.org/10.1046/j.1365-2664.2001.00626.x

WiLLIAMS, B.K. \& TitUS, K. (1988): Assessment of sampling stability in ecological applications of discriminant analysis. Ecology 69: 1275-85. http://dx.doi.org/10.2307/1941283

WINKLER D., BENDER F. \& NÉMETH T.M. (2014): A haris [Crex crex (Linnaeus, 1758)] bioakusztikai vizsgálata a Hanságban. Magyar Apróvad Közlemények 12: 135-149.

XIA, C., LIN, X., LIU, W., LLOYD, H. \& ZHANG, Y. (2017): Acoustic Identification of Individuals within Large Avian Populations: A Case Study of the Brownish-Flanked Bush Warbler, South-Central China. PLoS ONE 7(8): e42528. doi: https://doi.org/10.1371/journal.pone.0042528 